\title{
Production and nitrogen utilization in lactating dairy cows fed ground field peas with or without ruminally protected lysine and methionine
}

\author{
A. B. D. Pereira, ${ }^{* 1}$ N. L. Whitehouse, ${ }^{*}$ K. M. Aragona, ${ }^{*}$ C. S. Schwab,$\dagger^{2}$ S. F. Reis, ${ }^{*}$ and A. F. Brito ${ }^{* 3}$ \\ ${ }^{*}$ Department of Agriculture, Nutrition, and Food Systems, University of New Hampshire, Durham 03824 \\ †Schwab Consulting LLC, Boscobel, WI 53805
}

\begin{abstract}
Previous research has shown that cows fed $\geq 24 \%$ of the diet dry matter (DM) as field peas decreased milk yield as well as concentration and yield of milk protein, possibly due to reduced DM intake and limited supply of Lys and Met. Twelve multiparous and 4 primiparous lactating Holstein cows were randomly assigned to 1 of 4 diets in a replicated $4 \times 4$ Latin square design. The diets contained (DM basis) $34.8 \%$ corn silage, $15.2 \%$ grass-legume silage, $5.9 \%$ roasted soybean, $2.4 \%$ mineral-vitamin premix, $2.0 \%$ alfalfa pellets, and either (1) $36 \%$ ground corn, $2.4 \%$ soybean meal, and $1.3 \%$ urea (UR), (2) $29.7 \%$ ground corn, $9.8 \%$ soybean meal, $0.13 \%$ ruminally protected (RP) Lys, and $0.07 \%$ RP-Met (CSBAA), (3) 25\% ground field peas, $12.3 \%$ ground corn, and $2.4 \%$ soybean meal (FP), or (4) FP supplemented with $0.15 \%$ RP-Lys and $0.05 \%$ RP-Met (FPAA). Our objective was to test the effects of FP versus UR, FPAA versus CSBAA, and FPAA versus $\mathrm{FP}$ on milk yield and composition, $\mathrm{N}$ utilization, nutrient digestibility, ruminal fermentation profile, and plasma concentration of AA. Milk yield did not differ across diets. Compared with cows fed UR, those fed FP had greater DM intake, concentration and yield of milk true protein, apparent total-tract digestibility of fiber, urinary excretion of purine derivatives, and concentrations of total volatile fatty acids in the rumen and Lys in plasma, and less milk urea $\mathrm{N}$ and ruminal $\mathrm{NH}_{3}-\mathrm{N}$. The concentration of milk urea $\mathrm{N}$, as well as the concentration and yield of milk fat increased in cows fed FPAA versus CSBAA. Moreover, cows fed FPAA had greater ruminal concentration of total volatile fatty acids, increased proportions of acetate and isobutyrate,
\end{abstract}

\footnotetext{
Received October 11, 2016.

Accepted April 23, 2017.

${ }^{1}$ Present address: Purina Animal Nutrition LLC, Shoreview, MN 55126.

${ }^{2}$ Professor Emeritus, University of New Hampshire, Durham, NH 03824 .

${ }^{3}$ Corresponding author: andre.brito@unh.edu
}

and decreased proportions of propionate and valerate than those fed CSBAA. The plasma concentrations of His, Leu, and Phe decreased, whereas plasma Met increased and plasma Lys tended to increase in cows fed FPAA versus CSBAA. Concentration of milk true protein, but not yield, was increased in cows fed FPAA versus FP. However, cows fed FPAA showed decreased concentrations of His and Leu in plasma compared with those fed FP. Overall, compared with the CSBAA diet, feeding FPAA did not negatively affect milk yield and milk protein synthesis. Furthermore, RP-Lys and RPMet supplementation of the FP diet did not improve milk yield or milk protein synthesis, but decreased urinary urea $\mathrm{N}$ excretion.

Key words: dairy cow, ground field pea, milk yield, ruminally protected amino acid

\section{INTRODUCTION}

Field peas (or dry peas, split peas; Pisum sativum), a pulse crop commonly grown in the northern plains of the United States and Canadian provinces, are primarily used as human food, but also as livestock feed when food quality standards are not met (Gilbery et al., 2007). Field peas are one of the few feedstuffs that combine relatively high concentrations of $\mathrm{CP}$ and starch (Gilbery et al., 2007), making them a unique substitute for typical dairy protein and energy sources such as soybean meal, corn, and barley. Field peas may also be an alternative to soybean meal in organically certified dairies due to the increased risk for soybean meal to be genetically modified (Froidmont and Bartiaux-Thill, 2004). However, most of the RDP in field peas consists of soluble protein (SP), which may decrease milk yield and $\mathrm{N}$ utilization in lactating dairy cows, particularly at high levels $(\geq 24 \%$ of diet DM) of inclusion. Soluble protein is defined herein as true protein soluble in borate-phosphate buffer, but precipitable with tungstic acid (Licitra et al., 1996). Degradable protein or RDP is defined as dietary nitrogenous sources degraded by the ruminal microbiota. According to the NRC (2001), ruminally degraded feed $\mathrm{CP}$ provides a mixture of 
peptides, free $\mathrm{AA}$, and $\mathrm{NH}_{3}$ for microbial growth and synthesis of microbial protein.

Albrecht (2012) reported a quadratic decrease in DMI, as well as linear reductions in milk yield and concentration and yield of milk true protein in dairy cows fed incremental amounts of cracked field peas $(0$, 12,24 , or $36 \%$ of the diet DM) at expense of ground corn and soybean meal. These negative responses were more severe at high levels of supplementation (i.e., 24 and $36 \%$ of the diet DM), thereby suggesting that depressed DMI and deficiency in the supply of MP-Lys or MP-Met or both could be involved. However, we are not aware of any study to date that has tested the effects of ruminally protected (RP)-Lys and RP-Met supplementation to diets containing ground field peas (GFP) on milk yield and $\mathrm{N}$ utilization in dairy cows. It is also unknown how milk yield and milk protein synthesis are affected by feeding GFP compared with a NPN source such as urea.

Ammonia is the main $\mathrm{N}$ source for microbial protein synthesis (Nolan, 1975; Aharoni et al., 1991) and is essential for the growth of several species of ruminal bacteria (Allison, 1970; Bryant, 1973). On the other hand, a large number of studies have established that preformed AA, as free AA, peptides, or SP, increased microbial growth, fiber digestion, or both (Cotta and Russell, 1982; Chikunya et al., 1996; Griswold et al., 1996; Atasoglu et al., 1999; Carro and Miller, 1999). Thus, feeding GFP versus urea may increase microbial protein synthesis as GFP-SP releases free AA, peptides, and $\mathrm{NH}_{3}$ following degradation in the rumen, whereas urea only yields $\mathrm{NH}_{3}$ for microbial growth. Moreover, Reynal et al. (2007) reported that, on average, $10 \%$ of the total AA flow to the omasum consisted of soluble AA from feed origin (i.e., free AA, peptide AA, and SP AA). Of this $10 \%$, which represented $74 \mathrm{~g} / \mathrm{d}$ of omasal flow of dietary total soluble AA, only $8 \mathrm{~g} / \mathrm{d}$ came from the SP AA pool, suggesting extensive ruminal degradation of SP or low concentration of SP in the diets.

Our hypotheses were (1) cows fed $25 \%$ of the diet DM as GFP would improve milk yield and $\mathrm{N}$ utilization due to increased DMI, nutrient digestibility, and microbial protein synthesis [estimated as urinary excretion of purine derivatives (PD)] compared with cows fed urea; (2) milk yield and milk protein synthesis would be similar in cows fed diets containing ground corn plus soybean meal or GFP (25\% of the diet DM) with both rations formulated to yield a 3:1 MP-Lys to MP-Met ratio (7.2\% Lys and 2.4\% Met in MP; NRC, 2001) via RP-Lys and RP-Met supplementation; and (3) milk protein synthesis would increase in cows fed a diet that consisted of GFP formulated to yield a 3:1 MP-Lys to MP-Met ratio via RP-AA supplementation compared with GFP without RP-AA supplementation. We decided to feed $25 \%$ GFP because greater amounts have been shown to decrease DMI, milk yield, and N utilization, as well as ruminal and total-tract digestibility of fiber (Khorasani et al., 2001; Albrecht, 2012). The objective of our study was to test the effects of the experimental diets on milk yield and composition, $\mathrm{N}$ utilization, nutrient digestibility, ruminal fermentation profile, and plasma concentration of AA through the following pairwise comparisons: (1) GFP versus urea (i.e., FP vs. UR); (2) GFP versus ground corn plus soybean meal, both diets supplemented with RP-Lys and RP-Met (i.e., FPAA vs. CSBAA); and (3) FPAA versus FP.

\section{MATERIALS AND METHODS}

The experiment was conducted at the University of New Hampshire Fairchild Dairy Teaching and Research Center $\left(43^{\circ} 14^{\prime} \mathrm{N}, 70^{\circ} 95^{\prime} \mathrm{W}\right.$; Durham, NH) from June 29 to September 14, 2014. Care and handling of the animals were approved in accordance to the University of New Hampshire Institutional Animal Care and Use Committee guidelines (IACUC protocol no. 140402).

\section{Animals, Experimental Design, and Diets}

Twelve multiparous Holstein cows (4 ruminally cannulated) averaging (mean \pm SD) $97 \pm 36$ DIM and $684 \pm 61 \mathrm{~kg}$ of BW and 4 primiparous Holstein cows averaging $101 \pm 23 \mathrm{DIM}$ and $619 \pm 35 \mathrm{~kg}$ of BW at the beginning of the study were used. Cows were randomly assigned to treatment sequences in a replicated $4 \times 4$ Latin square design. Distribution of animals to squares was done to balance for differences in DIM, milk yield, and parity. Cows were housed in a tiestall barn with free access to water throughout the experiment. Each experimental period lasted $21 \mathrm{~d}$, with $14 \mathrm{~d}$ for diet adaptation and $7 \mathrm{~d}$ for data and sample collection. Diets were fed as TMR and were prepared twice daily, at 0630 and 1630 h, using a Super Data Ranger mixer (American Calan Inc., Northwood, NH). Feed was placed in individual wooden feed tubs $(90 \times 90 \times 90 \mathrm{~cm})$ with $30 \%$ of the daily TMR allocation offered at $0700 \mathrm{~h}$ and the remaining $70 \%$ at $1700 \mathrm{~h}$ to account for uneven intervals between feeding times (i.e., $10 \mathrm{~h}$ between 0700 and $1700 \mathrm{~h}$ and $14 \mathrm{~h}$ between 1700 and $0700 \mathrm{~h}$ ). The amount of TMR offered to the animals was recorded using the Super Data Ranger scale (American Calan Inc.). Refusals were collected daily before the afternoon feeding and weighed as done for the TMR. Feed offered was adjusted daily to yield approximately $5 \%$ refusals per animal. 
The experimental diets were formulated to contain (DM basis) $34.8 \%$ corn silage, $15.2 \%$ grass-legume silage, $5.9 \%$ roasted soybean, $2.4 \%$ minerals-vitamins premix, $2.0 \%$ alfalfa pellets, and either (1) $36 \%$ ground corn, $2.4 \%$ soybean meal, and $1.3 \%$ urea (UR); (2) $29.7 \%$ ground corn, $9.8 \%$ soybean meal, $0.13 \%$ RPLys supplement (Aji-Pro L; Ajinomoto Heartland Inc., Tokyo, Japan), and 0.07\% RP-Met supplement (Smartamine M; Adisseo, Antony, France) (CSBAA); (3) $25 \%$ GFP, $12.3 \%$ ground corn, and $2.4 \%$ soybean meal (FP); or (4) $25 \%$ GFP, $12.2 \%$ ground corn, $2.3 \%$ soybean meal, $0.15 \%$ RP-Lys (Aji-Pro L), and $0.05 \%$ RP-Met (Smartamine M) (FPAA). The RP-Lys and RP-Met were added last by pouring on the top of the ingredients already mixed in the Super Data Ranger mixer (American Calan Inc.) when preparing the CSBAA and FPAA diets.

\section{Feed Sampling and Analyses}

Two individual samples of corn and grass-legume silages were obtained daily and stored in a refrigerator at $4^{\circ} \mathrm{C}$ no longer than $4 \mathrm{~d}$. One set of 3 subsamples was pooled every $3 \mathrm{~d}$ and dried using a microwave (Model R-209KK 700 W, Sharp Electronics, Osaka, Japan) for adjustment of diets DM. The second set of 4 subsamples was pooled over $4 \mathrm{~d}$ and lyophilized for $48 \mathrm{~h}$ (Labconco Freeze Drier 5, Kansas City, MO). Samples of TMR and refusals were collected every $2 \mathrm{~d}$ after each feeding, refrigerated $\left(4^{\circ} \mathrm{C}\right)$ immediately after collection, pooled weekly by treatment, and dried in a forced-air oven at $55^{\circ} \mathrm{C}$ for $72 \mathrm{~h}$ (1380FMS; VWR Scientific, Radnor, PA). Ground corn, soybean meal, GFP, urea, and alfalfa pellet samples were collected weekly and lyophilized (Labconco Freeze Drier 5). Feeds (silages, GFP, and roasted soybean), TMR, and refusals collected during the last $7 \mathrm{~d}$ of each period were ground to pass through a 1-mm screen using a Wiley mill (Arthur H. Thomas Scientific, Philadelphia, PA), packed in labeled plastic bags, and shipped to a commercial laboratory for nutritional analyses (Dairy One Forage Laboratory, Ithaca, NY). Samples of ground corn, soybean meal, urea, and alfalfa pellets were collected and processed as the remaining dietary ingredients. However, because these 4 ingredients were purchased in single batches, only 1 composite sample per feed representing the entire study was shipped to Dairy One Forage Laboratory for nutritional analyses.

The following analyses were done in the TMR samples: absolute DM (method 930.15; AOAC International, 2006), total $\mathrm{N}$ (methods 990.03 and 992.23 967.07; AOAC International, 2006), NDF (method 6 in an Ankom Fiber Analyzer A2000 with $\alpha$-amylase and sodium sulfite; Ankom Technology, Fairpoint, NY; solutions as in Van Soest et al., 1991), ADF (method 5 in an Ankom Fiber Analyzer A2000; Ankom Technology; method 973.18, AOAC International, 1998), ether extract [extraction by a Soxtec HT6 System (Foss North America, Eden Prairie, MN) using anhydrous diethyl ether; method 2003.05, AOAC International, 2006), starch (YSI 2700 Select Biochemistry Analyzer; application note no. 319 (http://dairyone.com/wpcontent/ uploads/2014/02/Forage-Lab-Analytical-ProceduresListing-Alphabetical-July2015.pdf); YSI Inc., Life Sciences, Yellow Springs, OH), ash (method 942.05; AOAC International, 2006), and $\mathrm{Ca}$ and $\mathrm{P}$ (Thermo IRIS Advantage HX or ICAP 6300 intrepid inductively coupled plasma radial spectrometer after microwave digestion; CEM application note (http://dairyone.com/ wpcontent/uploads/2014/02/Forage-Lab-Analytical-

Procedures-Listing-Alphabetical-July2015.pdf) for acid digestion; CEM, Matthews, NC). In addition, TMR samples were analyzed for SP (Licitra et al., 1996), neutral detergent insoluble CP (LecoTruMac N Macro Determinator on NDF residue; Leco Corporation, St. Joseph, MI), acid detergent insoluble CP (LecoTruMac N Macro Determinator on ADF residue; Leco Corporation), lignin (Ankom Technology method 9; method 973.18, AOAC International, 1998), and ethanol-soluble carbohydrates (Hall et al., 1999). Silages, ground corn, soybean meal, GFP, roasted soybean, and alfalfa pellets were analyzed for absolute DM, total N, NDF, and ADF following the procedures reported for the TMR. Amino acids in these feedstuffs were analyzed using cationexchange HPLC coupled with postcolumn ninhydrin derivatization and quantification with norleucine as the internal standard (method 982.30; AOAC International, 2016) at the University of Missouri Experimental Station Chemical Laboratories (Columbia, MO); Trp was determined after alkaline hydrolysis (method 988.15; AOAC International, 2016). Starch was determined in ground corn and GFP, whereas SP was analyzed in ground corn, soybean meal, GFP, and urea following the methods reported above. Urea was also analyzed for absolute DM and total N. Refusals were analyzed for absolute DM, ash, NDF, ADF, starch, and total N following the procedures described previously.

\section{Milk Sampling and Analyses}

Cows were milked twice a day, at 0500 and $1600 \mathrm{~h}$, with milk yield recorded throughout the experiment. Milk samples were collected for 6 consecutive milking sessions (d 16-18) in each sampling period, preserved in tubes containing 2-bromo-2-nitropropan-1,3 diol, pooled by cow according to morning and afternoon 
milk weights, and refrigerated at $4^{\circ} \mathrm{C}$ until shipped to Dairy One Cooperative Inc. for determination of fat, true protein, lactose, and MUN by Fourier transform infrared spectroscopy using a MilkoScan model FT+ or 6000 (Foss Inc., Hillerød, Denmark) and SCC by flow cytometry in a Fossomatic FC or 5000 (Foss Inc.). Concentrations and yields of milk components were calculated as the average between the duplicate samples. Calculation of ECM was done based on Tyrrell and Reid (1965), whereas 4\% FCM was determined according to Gaines and Davidson (1923).

\section{Blood Sampling and Analyses}

Coccygeal blood samples were taken for 3 consecutive days (d 16-18) from all cows approximately $4 \mathrm{~h}$ after the 0700-h feeding into 2 vacutainer tubes containing EDTA (Monoject Covidien, Mansfield, MA). After collection, tubes were immediately transported to the laboratory and centrifuged $(2,155 \times g$ for 20 min at $4^{\circ} \mathrm{C}$ ) using an Eppendorf Centrifuge model 5810 (Eppendorf, Hamburg, Germany). Plasma from the first set of tubes was collected, composited by cow, and stored at $-20^{\circ} \mathrm{C}$ for later analyses of fatty acids and urea N (PUN). Concentration of plasma fatty acids was determined colorimetrically using an UV/visible spectrophotometer (Beckman Coulter Inc., Brea, CA) set at a wavelength of $550 \mathrm{~nm}$ using a commercially available kit $[\mathrm{HR}(2)$ Series; Wako Chemicals USA Inc., Richmond, VA]. Concentration of PUN was also determined colorimetrically (UV/visible spectrophotometer, Beckman Coulter Inc.) using the diacetyl-monoxime method (Rosenthal, 1955) and wavelength set a $540 \mathrm{~nm}$. Four millimeters of plasma from the second set of tubes were added to $40-\mathrm{mL}$ glass culture tubes containing 1 $\mathrm{mL}$ of $15 \%$ sulfosalicylic acid solution, homogenized using a vortex (Mini Vortexer; VWR International, Bridgeport, NJ), and kept for $10 \mathrm{~min}$ at $4^{\circ} \mathrm{C}$. Next, tubes were centrifuged $\left(2,155 \times g\right.$ for $20 \mathrm{~min}$ at $\left.4^{\circ} \mathrm{C}\right)$ and $0.6-\mu \mathrm{L}$ aliquots of supernatants were pooled over the $3 \mathrm{~d}$ of sampling by cow per period and stored in cryovials at $-80^{\circ} \mathrm{C}$ until shipped to the University of Missouri Experimental Station Chemical Laboratories for AA analyses following the methods of Deyl et al. (1986) and Fekkes (1996) using cation-exchange HPLC, as reported above.

\section{Ruminal, Urinary, and Fecal Sampling and Analyses}

Ruminal samples were taken from 4 multiparous cows (square 1) fitted with ruminal cannulas $(10 \mathrm{~cm}$ i.d.; Bar Diamond Inc., Parma, ID) on d 15 of each period immediately before the 0700-h feeding and at 1, 2, 4,
$6,8,10,12,14,16$, and $18 \mathrm{~h}$ thereafter. Samples were taken using a $40-\mathrm{cm}$ long, $2.5-\mathrm{cm}$ diameter polyvinyl chloride tube hooked to a volumetric flask attached to an $85-\mathrm{mL}$ vacuum bulb for suctioning (VWR international, Radnor, PA). The PVC tube was inserted in the rumen via an orifice in the cannula cap and the site of sampling was verified by hand via the ruminal cannula before a sample was taken. Samples were collected from the cranial, ventral, and caudal sacs at various depths, yielding a final volume of approximately $400 \mathrm{~mL}$ per sampling. Ruminal fluid was immediately transported to the laboratory, vortexed, and measured for $\mathrm{pH}$ using a portable pH meter (model SP20; VWR International, Bridgeport, NJ). Following $\mathrm{pH}$ readings, a subsample of $46.8 \mathrm{~mL}$ was acidified with $1.2 \mathrm{~mL}$ of $6 \mathrm{~N} \mathrm{HCl}$ into a centrifuge tube and frozen $\left(-20^{\circ} \mathrm{C}\right)$ for later analysis of $\mathrm{NH}_{3}$. Samples were thawed at room temperature, vortexed, and centrifuged at $3,125 \times g$ for $20 \mathrm{~min}$ at $22^{\circ} \mathrm{C}$. Next, $10 \mathrm{~mL}$ of supernatant was added to a beaker containing $1 \mathrm{~mL}$ of $\mathrm{pH}$ ionic strength adjuster (Orion 951211; Thermo Fisher Scientific, Chelmsford, MA), and gaseous $\mathrm{NH}_{3}$ released was measured using an ion-selective electrode meter (Orion Star A214 Benchtop pH/ISE Meter; Thermo Scientific, Waltham, MA) and finally converted to $\mathrm{NH}_{3}-\mathrm{N}$. A ruminal fluid subsample $(8 \mathrm{~mL})$ was added to a cryovial containing $2 \mathrm{~mL}$ of $50 \% \mathrm{H}_{2} \mathrm{SO}_{4}$ (vol/vol) and stored at $-80^{\circ} \mathrm{C}$ for later VFA analyses using a GC equipped with a flame ionization detector (model 3300; Varian Inc., Palo Alto, $\mathrm{CA}$ ) and a $2 \mathrm{~m} \times 2 \mathrm{~mm}$ glass column packed with $10 \%$ stationary phase $1200 / 1 \mathrm{H}_{3} \mathrm{PO}_{4}$ on $80 / 100$ Chromosorb W-AW media (Supelco Inc., Bellefonte, PA) at the West Virginia University Rumen Fermentation Profiling Laboratory (Morgantown, WV)

Spot urine samples from 8 multiparous cows (squares 1 and 2) were sampled for 3 consecutive days (d 16-18 in each period) every $6 \mathrm{~h}$ by stimulation of the pudendal nerve massaging the area below the vulva. On $\mathrm{d}$ 16, cows were sampled at 0000, 0600, 1200, and 1800 $\mathrm{h}$, with the sampling schedule advanced $2 \mathrm{~h}$ for each of the following $2 \mathrm{~d}$ to account for diurnal variation in the excretion of urinary metabolites (total of 12 spot samples). Urine samples were immediately transported to the laboratory and vortexed. Subsamples $(800 \mu \mathrm{L}$ per sampling point) were pooled over $3 \mathrm{~d}$, yielding a total of $9.6 \mathrm{~mL}$ of urine, which was placed in $50-\mathrm{mL}$ centrifuge tubes containing $38.4 \mathrm{~mL}$ of $0.072 \mathrm{~N} \mathrm{H}_{2} \mathrm{SO}_{4}$ and stored $\left(-20^{\circ} \mathrm{C}\right)$ for later analyses of creatinine, allantoin, uric acid, urea N, and total N. Subsamples of $3.5 \mathrm{~mL}$ of urine per sampling point were also added to $50-\mathrm{mL}$ centrifuge tubes containing $1.2 \mathrm{~mL}$ of $6 \mathrm{~N} \mathrm{HCl}$ and pooled over the 3 sampling days for later analysis of $\mathrm{NH}_{3}$ using the methodology described for the ruminal samples. 
After thawing at room temperature, urine samples were analyzed colorimetrically for concentrations of creatinine (assay kit no. 500701; Cayman Chemical Co., Ann Arbor, MI) using a microplate reader set at a wavelength of $492 \mathrm{~nm}$, allantoin (Chen et al., 1992), uric acid (assay kit no. 1045-225; Stanbio Laboratory, Boerne, TX), total N (micro-Kjeldahl analysis, AOAC, 1990; Dairy One Forage Laboratory), and urea N (as described for PUN). Urinary urea $\mathrm{N}$, allantoin, and uric acid were read at wavelengths of 540,522 , and $520 \mathrm{~nm}$, respectively, on a UV/visible spectrophotometer (Beckman Coulter Inc.). Daily urinary volume was estimated from the urinary concentration of creatinine assuming a constant creatinine excretion rate of $29 \mathrm{mg} / \mathrm{kg}$ of BW (Valadares et al., 1999). Urinary excretion of total PD was calculated by adding allantoin plus uric acid.

Fecal grab samples were collected directly from the rectum concurrently with urine (squares 1 and 2). Samples were pooled by cow based on fresh weight (about $200 \mathrm{~g} /$ sampling) over $3 \mathrm{~d}$ to obtain a single composite and stored at $-20^{\circ} \mathrm{C}$ in plastic bags. At the end of each sampling period, pooled fecal samples were thawed, placed in aluminum trays, and kept inside a forced-air oven at $55^{\circ} \mathrm{C}$ until completely dried (approximately 72 h). Dried samples were ground to pass through a 1-mm screen (Wiley mill) and analyzed for absolute DM, ash, total N, NDF, ADF, and starch, as described previously. Approximately $0.5 \mathrm{~g}$ of feces, TMR, and feeds were weighed into Ankom F57 bags (Ankom Technology), placed in 1 larger laundry bag, and inserted in the rumen of 1 ruminally cannulated lactating Holstein cow (190 DIM and $40.5 \mathrm{~kg} / \mathrm{d}$ of milk yield) for $12 \mathrm{~d}$. After removal from the rumen, bags were rinsed with tap water and the residue was analyzed for ADF as described above. Indigestible $\mathrm{ADF}$ was used as the internal marker to estimate fecal output of DM and apparent total-tract digestibility of nutrients (Cochran et al., 1986; Huhtanen et al., 1994).

\section{Diet Evaluation and Statistical Analyses}

The experimental diets were evaluated using the NRC (2001) version 1.1.9 (https://nanp-nrsp-9.org/ nrc-dairy-model, accessed Apr. 20, 2014). Actual feeds nutritional composition as reported in Table 1, and animal variables (i.e., DMI, milk yield and composition, DIM, and BW) were entered in the NRC (2001) version 1.1.9. Default values were used when specific feed nutrients were not available. As GFP is not listed in the feed library of the NRC (2001) version 1.1.9, ground corn was used and populated with actual GFP nutritional composition (Table 1). Protein fractions (i.e., A, B, and $\mathrm{C}$ ) and protein degradation rate values reported by Khorasani et al. (2001) were used. Concentrations of neutral detergent insoluble $\mathrm{CP}$, acid detergent insoluble $\mathrm{CP}$, and lignin were obtained from a GFP source used in subsequent study (A. F. Brito, unpublished data).

Data were analyzed using the MIXED procedure of SAS (SAS version 9.4; SAS Institute Inc., Cary, NC) according to a replicated $4 \times 4$ Latin square design. The following model was fitted for variables analyzed without repeated measures over time (i.e., intake, milk yield, concentrations and yields of milk components, nutrient digestibility, and urinary and plasma metabolites):

$$
\begin{aligned}
\mathrm{Y}_{\mathrm{ijkl}}= & \mu+\mathrm{S}_{\mathrm{i}}+\mathrm{P}_{\mathrm{j}}+\mathrm{C}_{\mathrm{k}(\mathrm{i})}+\mathrm{TRT}_{1} \\
& +\mathrm{S} \times \mathrm{TRT}_{\mathrm{il}}+\varepsilon_{\mathrm{ijkl}},
\end{aligned}
$$

where $Y_{\mathrm{ijk}}=$ dependent variable, $\mu=$ overall mean, $S_{i}=$ fixed effect of ith square, $P_{j}=$ fixed effect of jth period, $\mathrm{C}_{\mathrm{k}(\mathrm{i})}=$ random effect of kth cow within ith square, $\mathrm{TRT}_{1}=$ fixed effect of lth treatment, $\mathrm{S} \times \mathrm{TRT}_{\mathrm{il}}$ $=$ interaction between ith square and lth treatment, and $\varepsilon_{\mathrm{ijkl}}=$ error term.

The following model was fitted for variables using time of sampling (hour) as repeated measures over time (i.e., ruminal $\mathrm{pH}, \mathrm{VFA}$, and $\mathrm{NH}_{3}-\mathrm{N}$ ):

$$
\begin{aligned}
\mathrm{Y}_{\mathrm{ijkl}}=\mu & +\mathrm{P}_{\mathrm{i}}+\mathrm{C}_{\mathrm{j}(\mathrm{i})}+\mathrm{TRT}_{\mathrm{k}}+\varepsilon 1_{\mathrm{ijk}}+\mathrm{HOUR}_{\mathrm{l}} \\
& +\mathrm{TRT} \times \operatorname{HOUR}_{\mathrm{kl}}+\varepsilon 2_{\mathrm{ijkl}},
\end{aligned}
$$

where $Y_{\mathrm{ijkl}}=$ dependent variable, $\mu=$ overall mean, $\mathrm{P}_{\mathrm{i}}=$ fixed effect of ith period, $\mathrm{C}_{\mathrm{j}(\mathrm{i})}=$ random effect of $\mathrm{jth}$ cow within ith period, $\mathrm{TRT}_{\mathrm{k}}=$ fixed effect of kth treatment, $\varepsilon 1_{\mathrm{ijk}}=$ whole plot error, $\mathrm{HOUR}_{\mathrm{l}}=$ fixed effect of lth sampling hour, TRT $\times \mathrm{HOUR}_{\mathrm{kl}}=$ interaction between kth treatment and lth sampling hour, and $\varepsilon 2_{\mathrm{ijk}}=$ subplot error term. The covariance structure spatial power resulted in the least Akaike information criterion compared with unstructured, heterogeneous autoregressive, compound symmetry, and spatial exponential [SP(EXP)], and was retained in the final model; cow (period) was used as the subject of the repeated statement.

Planned contrasts were used to compare the effects of (1) FP versus UR; (2) FPAA versus CSBAA; and (3) FPAA versus FP. Significance was declared at $P \leq 0.05$ and trends at $0.05<P \leq 0.10$.

\section{RESULTS AND DISCUSSION}

\section{Diets Nutritional Composition}

The nutritional composition of the ingredients used in the experimental diets is presented in Table 1, and the ingredient and nutritional composition of the 
Table 1. Nutritional composition of feed ingredients used in the experimental diets ${ }^{1}$

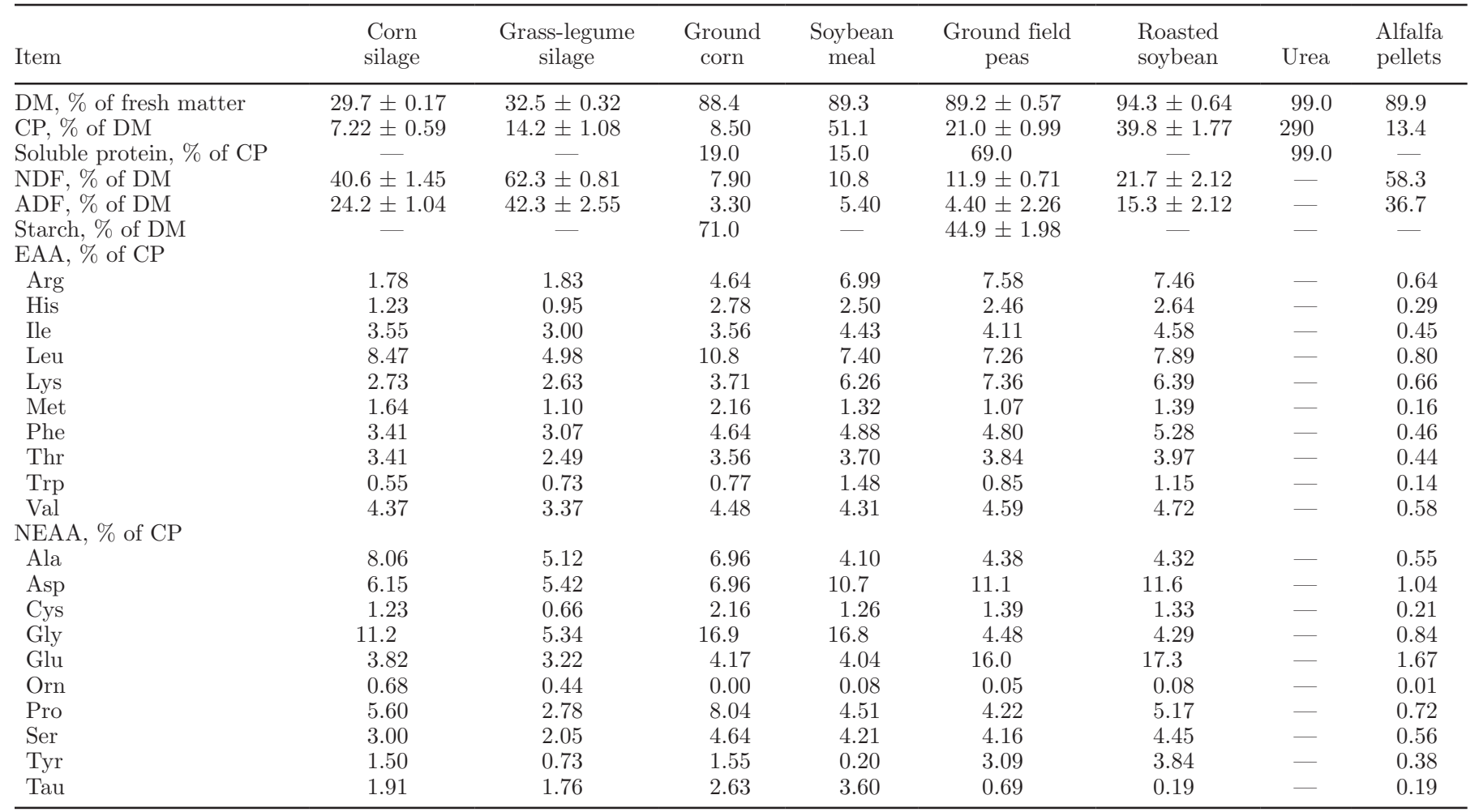

${ }^{1}$ Means \pm SD only for feed samples that were pooled by period.

experimental diets are presented in Table 2. Overall, the nutritional composition of the experimental diets followed the nutritional profile of the individual feed ingredients. For instance, the concentration of SP was, on average, $25 \%$ numerically greater in FP and FPAA than CSBAA, but $5.4 \%$ less when compared with UR. The concentration of starch was numerically greater in $\mathrm{UR}$ and CSBAA (mean $=34.8 \%$ ) compared with FP and FPAA (mean $=31.7 \%$ ) as a result of the greater concentration of starch in ground corn than GFP (Table 1).

\section{Animal Production, Milk Composition, and Plasma Metabolites}

Dry matter intake was less $(-1.3 \mathrm{~kg} / \mathrm{d} ; P<0.01)$ in cows fed UR compared with those fed FP (Table 3). This reduction in DMI may have been caused by decreased apparent total-tract digestibilities of NDF and ADF in cows fed UR (Table 4). Poor palatability as a result of high levels of urea supplementation $(>1 \%$ of the diet DM) may further explain the depression in DMI (Brito and Broderick, 2007; Kertz, 2010). In contrast, DMI was not affected when comparing FPAA versus CSBAA or FPAA versus FP (Table 3 ). The lack of response in DMI with feeding FPAA versus CSBAA agrees with previous research, in which lactating dairy cows were fed incremental amounts of a GFP-based concentrate $(0,10,20$, or $30 \%$ of the diet DM) as a replacement for a soybean meal- and barley-based concentrate (Khorasani et al., 2001). Both milk yield and $4 \%$ FCM were similar among treatments and averaged 42.5 and $38.6 \mathrm{~kg} / \mathrm{d}$, respectively (Table 3 ). Cows fed FP tended to have greater ECM $(P=0.08 ;+1.5 \mathrm{~kg} / \mathrm{d})$ than those fed UR, but no effects were observed for FPAA versus CSBAA or FPAA versus FP. Milk yield was also not affected when cows were offered field peas (extruded, raw, ground, or expanded) ranging from 10 to $30 \%$ of the diet DM (Petit et al., 1997; Khorasani et al., 2001; Masoero et al., 2006; Vander Pol et al., 2008).

The concentration of milk fat did not differ when comparing FP versus UR or FPAA versus FP. In contrast, the concentration of milk fat increased $(P=$ 0.01) in the FPAA diet compared with the CSBAA counterpart. The concentration of plasma Met was also greater $(15.2 \% ; P<0.01)$ in cows fed FPAA than in those fed CSBAA (Table 6), thereby suggesting that more Met was available as a methyl donor for choline synthesis. Choline, as phosphatidylcholine, contributes to fatty acid transportation in the blood, which may have resulted in more lipoprotein triacylglycerols available for fat synthesis in the mammary gland (Erdman 
et al., 1984; Piepenbrink and Overton, 2003). However, starch intake, which may affect milk fat concentration by depressing ruminal $\mathrm{pH}$ only tended to increase $(0.43$ $\mathrm{kg} / \mathrm{d} ; P=0.10)$ in cows offered CSBAA versus FPAA (Table 3). Interestingly, despite a greater difference (63\%; $P<0.001$; Table 6$)$ in plasma concentration of Met with feeding FPAA versus FP, no change in milk fat concentration was observed. Therefore, we found no conclusive explanation for the increase in milk fat concentration in cows fed FPAA compared with CSBAA. Milk fat yield followed milk fat concentration and did not differ when comparing FP versus UR or
FPAA versus FP, but increased $(P=0.04)$ with feeding FPAA versus CSBAA (Table 3 ).

Milk true protein concentration $(P=0.02)$ and yield $(P=0.03)$ were greater in cows fed FP compared with those fed UR (Table 3 ). In a previous study (Brito and Broderick, 2007), cows fed urea also showed a less concentration and yield of milk true protein than those fed soybean meal or canola meal. Similar to urea, CP from GFP is rapidly degraded in the rumen (Vander Pol et al., 2009); however, in addition to $\mathrm{NH}_{3}$, preformed AA and peptides are produced after GFP-RDP proteolysis, which can further stimulate microbial protein synthesis

Table 2. Ingredient and nutritional composition of the experimental diets

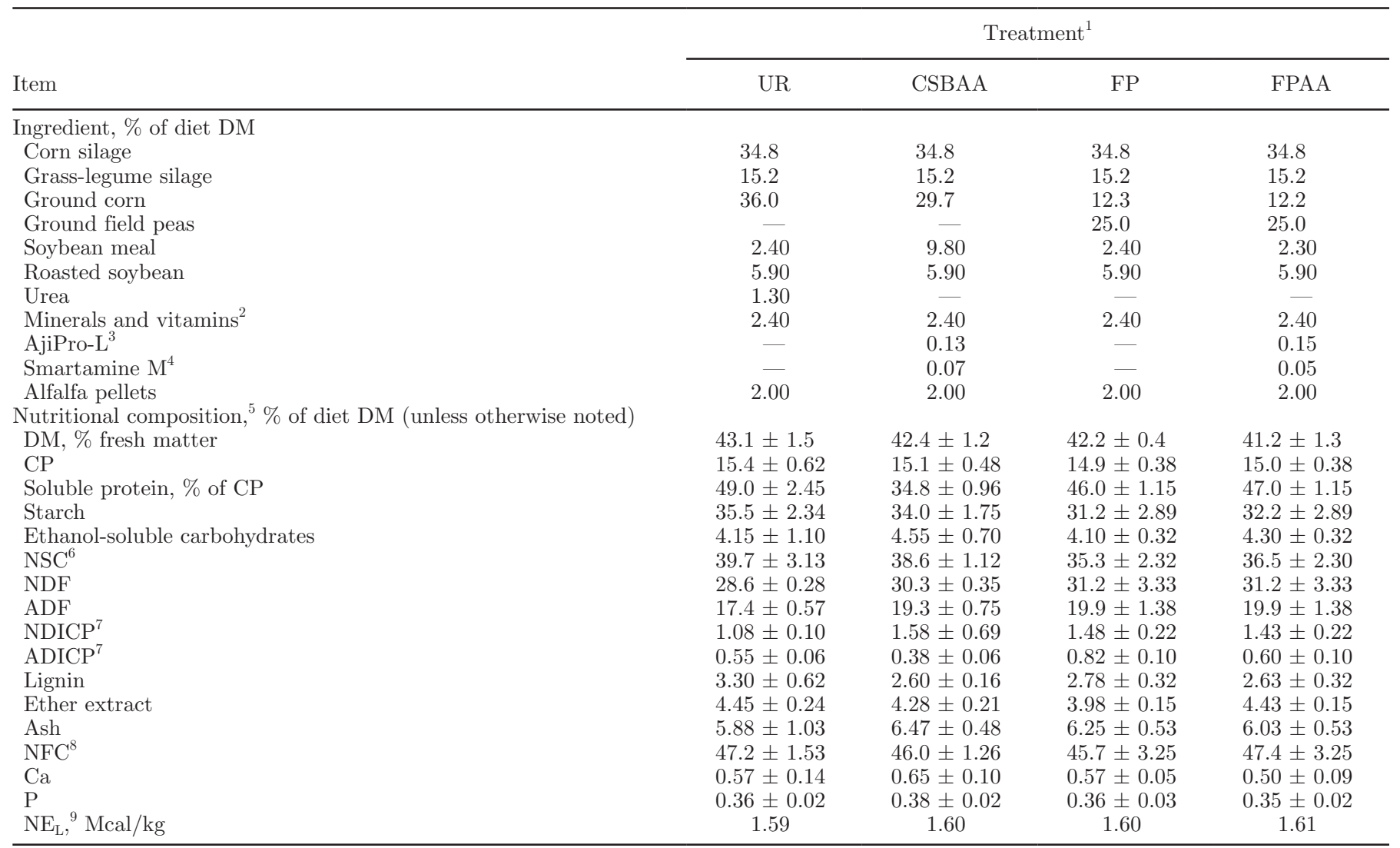

${ }^{1} \mathrm{UR}=$ urea; CSBAA $=$ ground corn plus soybean meal supplemented with ruminally protected Lys and Met; FP = ground field peas; FPAA $=$ ground field peas supplemented with ruminally protected Lys and Met.

${ }^{2}$ Mineral and vitamin mix provided, on an as-fed basis, $297 \mathrm{mg} / \mathrm{kg}$ of monensin sodium (Rumensin; Elanco, Greenfield, IN), 11.3\% Ca, 1.76\% $\mathrm{P}, 5.98 \% \mathrm{Mg}, 6 \% \mathrm{~K}, 3 \% \mathrm{~S}, 15 \mathrm{mg} / \mathrm{kg}$ of Co, $650 \mathrm{mg} / \mathrm{kg}$ of Cu, $50 \mathrm{mg} / \mathrm{kg}$ of I, $1,200 \mathrm{mg} / \mathrm{kg}$ of Mn, $8.97 \mathrm{mg} / \mathrm{kg}$ of Se, 3,700 mg/kg of Zn, and $87.1 \mathrm{kIU} / \mathrm{kg}$ of vitamin A.

${ }^{3}$ AjiPro-L (Ajinomoto Heartland Inc., Tokyo, Japan); ruminally protected Lys supplement.

${ }^{4}$ Smartamine M (Adisseo, Antony, France); ruminally protected Met supplement.

${ }^{5}$ Determined from TMR samples pooled by period (means $\pm \mathrm{SD}$ ).

${ }^{6} \mathrm{NSC}=$ starch + ethanol-soluble carbohydrates.

${ }^{7} \mathrm{NDICP}=$ neutral detergent insoluble $\mathrm{CP} ; \mathrm{ADICP}=$ acid detergent insoluble $\mathrm{CP}$.

${ }^{8} \mathrm{NFC}=100-[\mathrm{CP} \%+(\mathrm{NDF} \%-\mathrm{NDICP} \%)+$ ether extract $\%+\operatorname{ash} \%]$

${ }^{9}$ Determined using the NRC (2001) with actual feed nutritional composition and animal variables (i.e., DMI, milk yield and composition, DIM, and $\mathrm{BW}$ ). 
PEREIRA ET AL.

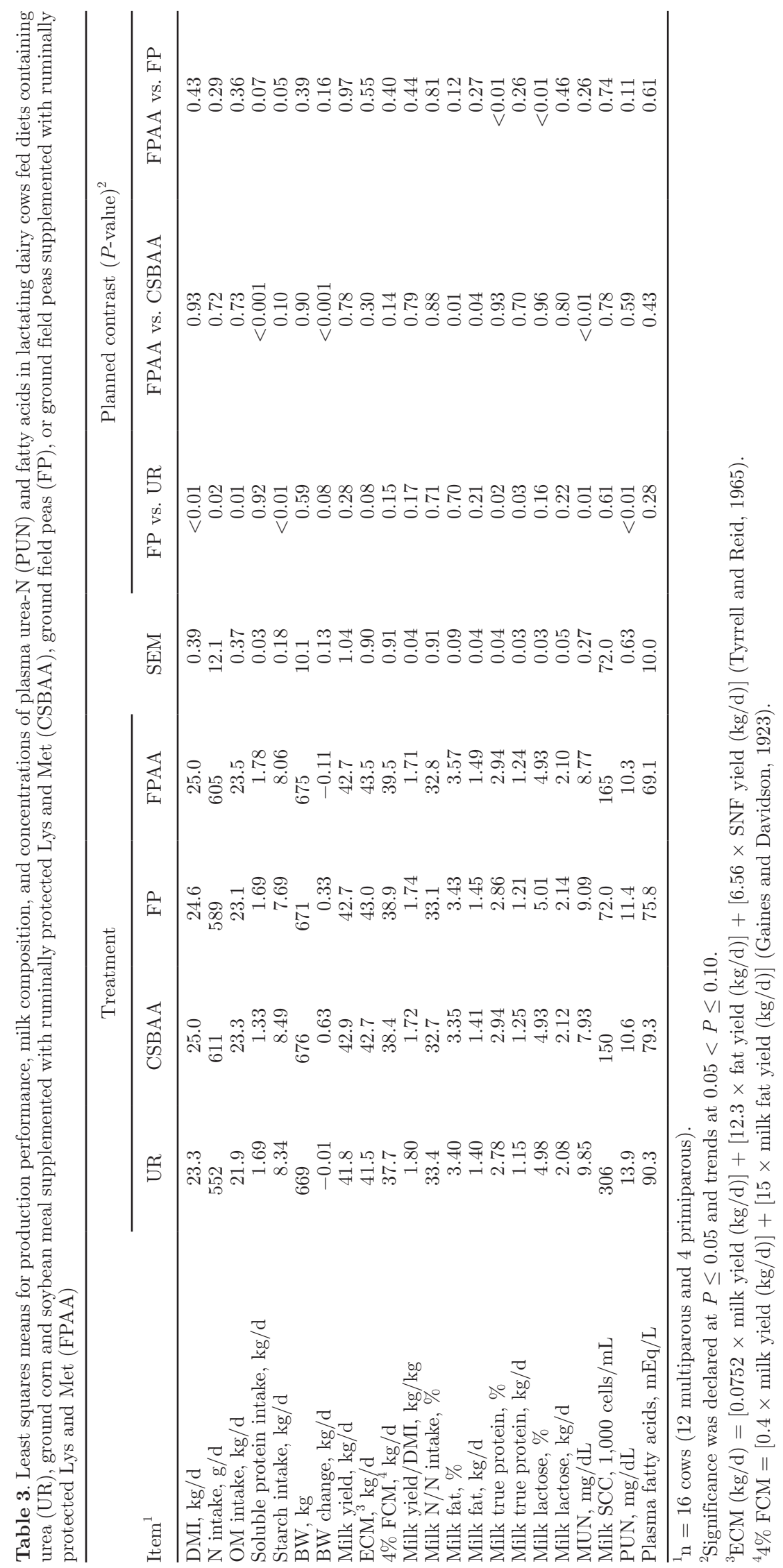


GROUND PEAS AND AMINO ACID SUPPLEMENTATION

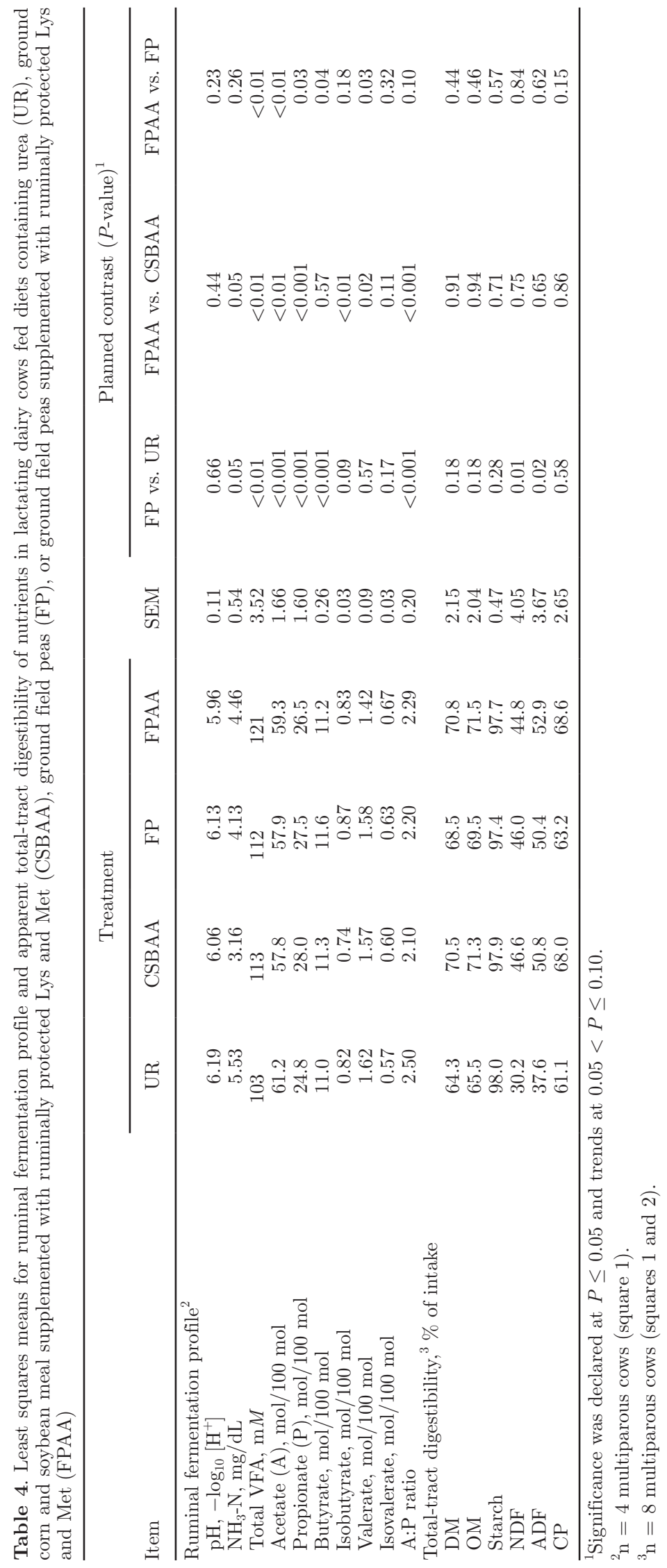


(Cotta and Russell, 1982; Argyle and Baldwin, 1989; Carro and Miller, 1999). Moreover, a small fraction of dietary SP escapes ruminal degradation and is available in the small intestine for animal use (Reynal et al., 2007). Intake of DM (Table 3), urinary excretion of PD (Table 5), and plasma concentration of Lys (Table 6) were significantly greater with feeding FP versus UR, and these results are consistent with increased concentration and yield of milk true protein in the FP diet.

Although the concentration and yield of milk true protein did not differ in cows fed FPAA versus CSBAA, milk true protein concentration was increased $(P<0.01)$ when feeding FPAA versus FP (Table 3 ). The plasma concentration of Met was $63 \%$ greater $(P$ $<0.01$ ) in cows fed FPAA rather than FP (Table 6), thus indicating that Met may have played a role on improving the concentration of milk true protein in cows fed FPAA, as DMI, milk yield, and urinary excretion of PD were similar between FPAA and FP diets. Furthermore, despite the significant increase in starch intake $(0.37 \mathrm{~kg} / \mathrm{d}$; Table 3$)$ in cows fed FPAA versus $\mathrm{FP}$, the difference between treatments was likely too small to influence the concentration of true protein in milk or Met in plasma. For instance, a larger difference in starch intake $(2.1 \mathrm{~kg} / \mathrm{d}$ ) between normal- (mean = $26.5 \%)$ and reduced-starch $($ mean $=18.2 \%$ ) diets did not affect DMI, concentration of milk true protein, and omasal flow of bacterial NAN (Fredin et al., 2015). Milk true protein yield did not change and averaged $1.23 \mathrm{~kg} / \mathrm{d}$ when feeding FPAA versus FP (Table 3 ).

No significant differences were observed in the concentration of milk lactose between FP versus UR (mean $=4.96 \%)$ and FPAA versus CSBAA $($ mean $=4.93 \%)$ (Table 3). In contrast, cows fed FPAA had less $(P<$ 0.01) milk lactose concentration than those fed FP, despite the same milk volume between these 2 diets (Table 3). Similarly, the ruminal molar proportion of propionate was less in cows fed FPAA than in those fed FP $(P=0.03$; Table 4$)$, which is consistent with the decreased concentration of lactose in milk as propionate is used for glucose synthesis in ruminants. However, the ruminal concentration of total VFA was greater in the FPAA than in the FP diet $(P<0.01$; Table 4$)$; therefore, the relationship between the proportion of propionate in the rumen and milk lactose should be interpreted cautiously. Milk lactose yield did not differ and averaged $2.11 \mathrm{~kg} / \mathrm{d}$ across treatments (Table 3 ).

The concentrations of MUN and PUN were significantly less in cows fed FP than UR (Table 3). Ground field peas RDP is presumably less quickly degraded in the rumen than urea RDP, possibly explaining the observed decrease in MUN and PUN when feeding FP. In addition, the ruminal concentration of $\mathrm{NH}_{3}-\mathrm{N}$ was less $(P=0.05)$ in cows fed FP than UR (Table 4$)$, suggesting a smaller pool of $\mathrm{NH}_{3}$ for ureagenesis in the liver. Cows fed FPAA had greater $(P<0.01)$ MUN than those fed CSBAA, whereas no difference was detected between FPAA versus FP. These results are not surprising, as the average intake of SP increased by $0.45 \mathrm{~kg} / \mathrm{d}$ when cows were fed FPAA compared with CSBAA $(P<0.001)$, but only tended to increase $(P=$ $0.07 ; 0.10 \mathrm{~kg} / \mathrm{d}$ ) in cows fed FPAA versus FP (Table 3 ). Previous studies showed that cows fed $\geq 20 \%$ of the diet DM as field peas (raw, extruded, or cracked) had greater MUN than those fed corn-soybean meal (Petit et al., 1997; Albrecht, 2012). However, no change in MUN was observed when GFP or rolled field peas were fed at $15 \%$ of the diet DM (Vander Pol et al., 2008, 2009), possibly due to a less dietary concentration of SP than that from the studies of Petit et al. (1997) and Albrecht (2012).

\section{Ruminal Metabolism and Apparent Total-Tract Digestibility of Nutrients}

Mean ruminal $\mathrm{pH}$ was similar and averaged 6.09 across treatments (Table 4). The minimum ruminal $\mathrm{pH}$ recorded were $5.50(1500 \mathrm{~h}), 5.37(1900 \mathrm{~h}), 5.30$ (1100 $\mathrm{h})$, and $5.16(2100 \mathrm{~h})$ in cows fed UR, CSBAA, FP, and FPAA, respectively (data not shown). The concentration of starch was above $30 \%$ of the diet DM in all 4 treatments (Table 2), thereby contributing to the drop in ruminal $\mathrm{pH}$ below 5.80. According to Knowlton et al. (1998) and Broderick and Radloff (2004), mean ruminal $\mathrm{pH}$ ranged from 5.63 to 6.27 in lactating dairy cows fed diets with starch concentration that varied from 31.4 to $36 \%$, which are ranges similar to those observed in the current study. However, the concentration of forage NDF averaged $25 \%$ in the 4 diets used herein (data not shown), and may have provided adequate physically effective fiber to keep mean ruminal $\mathrm{pH}$ above 5.80 despite feeding high-starch diets. Based on the NRC (2001), the minimum recommended concentration of forage NDF should be $19 \%$ in diets with at least $25 \%$ NDF content, and $15 \%$ forage NDF in diets with at least $33 \%$ NDF to promote ruminal and animal health.

The ruminal concentration of $\mathrm{NH}_{3}-\mathrm{N}$ was less $(P$ $=0.05)$ in cows fed FP than in those fed UR, and greater with feeding FPAA versus CSBAA $(P=0.05)$; no difference in ruminal $\mathrm{NH}_{3}-\mathrm{N}$ concentration was detected when comparing FPAA with FP (Table 4). Urea degradation by microbial ureases yields $\mathrm{NH}_{3}$ and $\mathrm{CO}_{2}$ (Reynolds and Kristensen, 2008; Wu, 2013), which is consistent with the increased concentration of ruminal $\mathrm{NH}_{3}-\mathrm{N}$ when comparing UR versus FP. Ruminal $\mathrm{NH}_{3}-\mathrm{N}$ concentration was also elevated in cows offered FPAA 
versus CSBAA, probably as a result of increased SP intake as discussed earlier. Vander Pol et al. (2009) reported that the ruminal concentrations of $\mathrm{NH}_{3}-\mathrm{N}$ and total free AA were greater in lactating dairy cows fed GFP than soybean meal plus corn, suggesting more proteolysis and deamination of dietary AA with increased intake of SP. Khorasani et al. (2001) observed a linear increase in the ruminal concentration of $\mathrm{NH}_{3}-\mathrm{N}$ in lactating dairy cows fed diets where a soybean meal- and barley-based concentrate was replaced by incremental amounts of a GFP-based concentrate.

The ruminal concentration of total VFA was greater $(P<0.01$; Table 4$)$ in cows offered FP than UR, which is possibly explained by increased OM intake with feeding FP (Table 3). The molar proportion of acetate increased $(P<0.001)$ when feeding UR versus FP, with opposite responses observed for that of propionate $(P$ $<0.001)$, butyrate $(P<0.001)$, and isobutyrate $(P$ $=0.09)$. The acetate-to-propionate ratio decreased $(P$ $<0.001$ ) in cows fed FP compared with UR due to a decrease in the molar proportion of acetate and an increase in that of propionate (Table 4). The major nutritional differences between UR and FP were the source of starch and RDP. Thus, it is conceivable that differences in ruminal RDP and starch degradabilities were responsible for the changes in the VFA profile between UR and FP diets. In fact, Offner et al. (2003) reported greater degradability of starch from GFP than from ground corn.

Compared with cows fed CSBAA, those fed FPAA had greater ruminal concentration of total VFA $(P<$ $0.01)$, as well as increased proportions of acetate $(P<$ $0.01)$ and isobutyrate $(P<0.01)$ and decreased proportions of propionate $(P<0.001)$ and valerate $(P=0.02)$ (Table 4). The acetate-to-propionate ratio increased $(P$ $<0.001$ ) when feeding FPAA versus CSBAA due to increased molar proportion of acetate in cows offered FPAA and decreased molar proportion of propionate in those offered CSBAA (Table 4). Previous studies (Khorasani et al., 2001; Masoero et al., 2006; Vander Pol et al., 2009) conducted with lactating dairy cows showed inconsistent results in the ruminal concentration of total VFA and molar proportion of individual VFA when replacing soybean meal and corn or barley with field peas (ground, raw, extruded, or expanded). These data collectively suggest that differences in the ingredient composition of the basal diets, forage-to-concentrate ratio, dietary levels of field peas and starch, starch degradability, and method of grain processing all may have influenced ruminal fermentation processes.

Whereas the ruminal concentration of total VFA $(P$ $<0.01)$ and the molar proportion of acetate $(P<0.01)$ were greater in cows fed FPAA than in those fed FP, the opposite was observed for the molar proportions of propionate $(P=0.03)$, butyrate $(P=0.04)$, and valerate $(P=0.03)$ (Table 4$)$. The major nutritional difference between FP and FPAA diets was supplementation with RP-Lys and RP-Met. Therefore, we cannot explain, based on the present results, the differences in ruminal VFA profile when comparing FP versus FPAA, as well as the lack of a consistent pattern of change in VFA across these 2 diets. In addition, the $0.37-\mathrm{kg} / \mathrm{d}$ increase in starch intake $(P=0.05$; Table 3$)$ in cows fed FPAA versus FP was probably not large enough to elicit substantial changes in ruminal fermentation processes and VFA profile.

The apparent total-tract digestibilities of DM, OM, starch, and CP did not differ across treatments and averaged $68.5,69.5,97.8$, and $65.2 \%$, respectively (Table 4). In contrast, the apparent total-tract digestibilities of NDF and ADF were greater in cows fed FP versus UR, which may be associated with increased availability of AA and peptides for microbial growth after ruminal degradation of SP from GFP. Previous research has established that preformed AA, as free AA, peptides, or SP, stimulated microbial growth, fiber digestion, or both (Cotta and Russell, 1982; Chikunya et al., 1996; Griswold et al., 1996; Atasoglu et al., 1999; Carro and Miller, 1999). In fact, the urinary excretion of PD was greater $(P<0.01)$ when feeding FP compared with UR (Table 5).

\section{Nitrogen Metabolism}

The outputs of milk $\mathrm{N}$, urinary $\mathrm{N}$, fecal $\mathrm{N}$, and manure $\mathrm{N}$, as well as $\mathrm{N}$ balance (i.e., $\mathrm{N}$ intake - $\mathrm{N}$ output) expressed in amount $(\mathrm{g} / \mathrm{d})$ or as a proportion of $\mathrm{N}$ intake did not differ in cows fed FP versus UR or FPAA versus CSBAA (Table 5). Similarly, the urinary excretion of $\mathrm{NH}_{3}-\mathrm{N}$ expressed in amount $(\mathrm{g} / \mathrm{d})$ or as a proportion of $\mathrm{N}$ intake or total urinary $\mathrm{N}$ excretion was not changed with feeding FP versus UR or FPAA versus CSBAA (Table 5). However, the urinary excretion of urea $\mathrm{N}$ (g/d and \% N of intake) was significantly lower in cows fed FP versus UR, but did not change when expressed as a proportion of total urinary $\mathrm{N}$ excretion (Table 5). Decreased urinary excretion of urea $\mathrm{N}$ (\% of $\mathrm{N}$ intake) in cows fed FP versus UR is consistent with the reduction in ruminal $\mathrm{NH}_{3}-\mathrm{N}$ concentration (Table 4), as $\mathrm{NH}_{3}$ is converted to urea in the liver. The urinary excretions of allantoin $(15.3 \% ; P<0.01)$ and PD $(14.9 \% ; P<$ 0.01 ) were greater when feeding FP compared with UR (Table 5), as discussed earlier. Compared with CSBAA, feeding FPAA did not change the urinary excretion of urea $\mathrm{N}(\mathrm{g} / \mathrm{d}$ and $\% \mathrm{~N}$ of intake), and only tended $(P=$ $0.09)$ to increase when expressed as a proportion of to- 
tal urinary $\mathrm{N}$ (Table 5 ). However, these results were not expected because the concentration of ruminal $\mathrm{NH}_{3}-\mathrm{N}$ and intake of SP were both greater in cows fed FPAA compared with those fed CSBAA.

Whereas the amount $(\mathrm{g} / \mathrm{d})$ of $\mathrm{N}$ secreted in milk $(P$ $=0.09)$ and $\mathrm{N}$ balance $(P=0.06)$ tended to increase in cows fed FPAA versus FP, that excreted in urine $(P=$ $0.07)$ and manure $(P=0.08)$ tended to decrease with feeding FPAA (Table 5). When expressed as proportions of $\mathrm{N}$ intake, the urinary excretion of $\mathrm{N}$ tended $(P$ $=0.06)$ to decrease and that of manure $\mathrm{N}$ decreased $(P=0.04)$ with feeding FPAA versus $\mathrm{FP}$, whereas $\mathrm{N}$ balance tended $(P=0.06)$ to increase in the FPAA diet (Table 5). The amount of $\mathrm{NH}_{3}-\mathrm{N}(P=0.04)$ and urea $\mathrm{N}(P<0.01)$ excreted in the urine, as well as the urinary excretions of $\mathrm{NH}_{3}-\mathrm{N}(P=0.04)$ and urea $\mathrm{N}(P$ $<0.01$ ), as proportions of $\mathrm{N}$ intake were all decreased in cows fed FPAA versus FP (Table 5). Collectively, these results appear to indicate that RP-Lys and RPMet supplementation improved or tended to improve $\mathrm{N}$ utilization in lactating dairy cows fed FPAA versus FP.

\section{Plasma Concentration of AA}

The plasma concentrations of Ile, Val, Lys, total branched-chain AA, and total EAA were greater $(P \leq$ 0.02 ) in cows fed FP versus UR, whereas the plasma concentration of Thr tended $(P=0.09)$ to increase with feeding FP (Table 6 ). These results were expected because of the increased supply of SP from GFP. Moreover, the urinary excretion of $\mathrm{PD}$ was also greater in cows fed FP versus UR, suggesting increased microbial protein flow to the small intestine. Brito et al. (2007) reported that the omasal flows of bacterial NAN, RUP, and all individual EAA were greater in cows fed true protein sources, such as soybean meal, cottonseed meal, or canola meal, compared with urea. The plasma concentrations of the NEAA Cit, Cys, Gln, Gly, and Pro decreased $(P \leq 0.02)$ in cows fed FP versus UR, whereas Ala concentration in plasma increased $(P=$ 0.02 ) with feeding FP (Table 6 ). These results are possibly explained by differences in DMI, microbial protein synthesis, and NEAA profile of the feedstuffs used in the UR and FP diets.

The concentrations of His $(P<0.01)$ and Leu $(P$ $=0.01)$ in plasma decreased in cows fed FPAA versus CSBAA, whereas plasma Met increased $(P<0.01)$ and plasma Lys tended $(P=0.08)$ to increase with feeding FPAA (Table 6). These data showed that supplementing GFP with RP-Lys and RP-Met was an effective strategy to increase plasma Lys and Met relative to CSBAA. Decreased concentrations of His and Leu in cows fed FPAA cannot be explained by DMI, urinary excretion of PD, and intakes of His and Leu (data not shown), as these variables did not differ between CSBAA and FPAA. Based on the NRC (2001) model, the MP balance in cows fed FPAA averaged $-407 \mathrm{~g} / \mathrm{d}$, and was $150 \%$ less than that in cows fed CSBAA $(-163 \mathrm{~g} / \mathrm{d}$; Table 7). Lee et al. (2012) and Giallongo et al. (2016) showed that His appears to be the third-limiting AA after Lys and Met in MP-deficient diets, which ranged from -22 to $-385 \mathrm{~g} / \mathrm{d}$ in their experiments.

The concentrations of His $(P<0.01)$, Leu $(P=$ $0.02)$, and Phe $(P=0.03)$ in plasma decreased in cows fed FPAA versus FP, whereas those of Met and total sulfur AA increased with feeding FPAA (Table 6). Patton et al. (2015) reported that increased postruminal supply of either Lys or Met alone caused significant changes in the plasma concentrations of several EAA. However, Met appeared to be more potent than Lys, causing a decrease in the concentrations of all EAA except Arg and Lys, whereas Lys caused a decrease in both His and Phe (Patton et al., 2015). The plasma concentrations of the NEAA Asn $(P=0.05)$, Gly $(P=$ $0.04)$, Ser $(P<0.001)$, and Tyr $(P<0.01)$ decreased, and those of Cys $(P<0.001)$ and cystathionine $(P<$ 0.001) increased with feeding FPAA versus FP (Table 6). Increased concentrations of Cys and cystathionine, in addition to plasma Met, are consistent with RPMet supplementation. As proposed by Berthiaume et al. (2001), decreased concentration of plasma AA as a consequence of feeding RP-Met to lactating dairy cows may be associated with (1) a decrease in absorption of AA, (2) an increase in hepatic removal of AA, and (3) an effect on AA utilization by other tissues (e.g., muscle). For instance, cows fed FPAA had a positive N balance (i.e., $8.92 \%$ of $\mathrm{N}$ intake), whereas a negative $\mathrm{N}$ balance (i.e., $-4.62 \%$ of $\mathrm{N}$ intake) was observed in cows fed FP (Table 5).

\section{Evaluation of the Experimental Diets}

The NRC (2001) diets evaluation are presented in Table 7; $\mathrm{NE}_{\mathrm{L}}$-allowable milk in cows fed UR was 3.3 $\mathrm{kg} / \mathrm{d}$ numerically less $(-8 \%)$ than actual milk yield, suggesting underestimation by the NRC (2001). However, the differences between actual milk yield versus $\mathrm{NE}_{\mathrm{L}}$-allowable milk in cows fed CSBAA, FP, and FPAA were small and ranged from 0 to $3.1 \%$. The actual milk yield was $28.6,9.4,27.5$, and $27.8 \%$ numerically greater than the MP-allowable milk in cows fed UR, CSBAA, FP, and FPAA, respectively, indicating that the NRC (2001) underestimated MP supply. Supplies (\% of DMI) of RDP and RUP were numerically lowest and greatest, respectively, in cows offered CSBAA, which is consistent with the smallest concentration of $\mathrm{SP}$ in 
GROUND PEAS AND AMINO ACID SUPPLEMENTATION

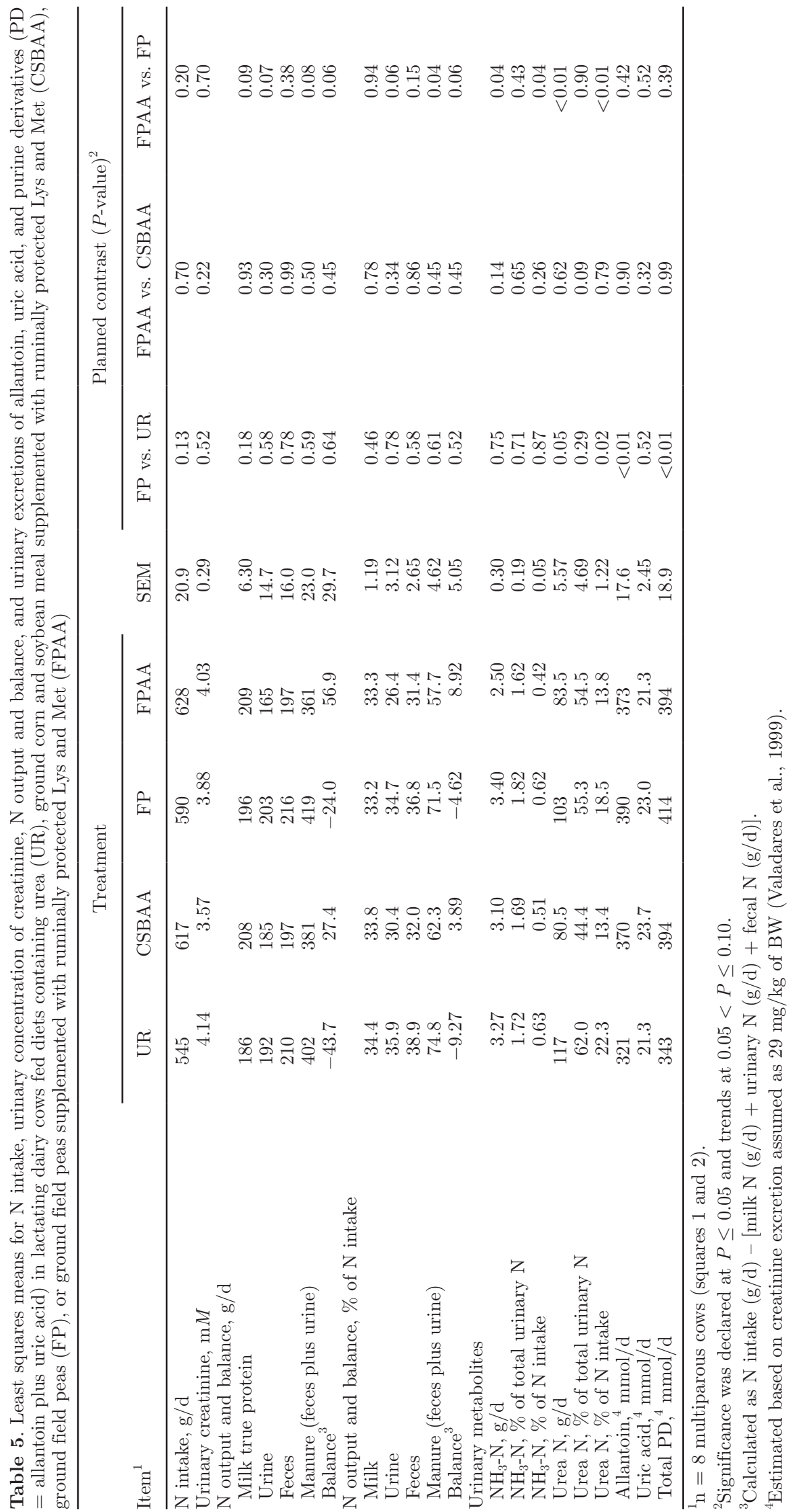




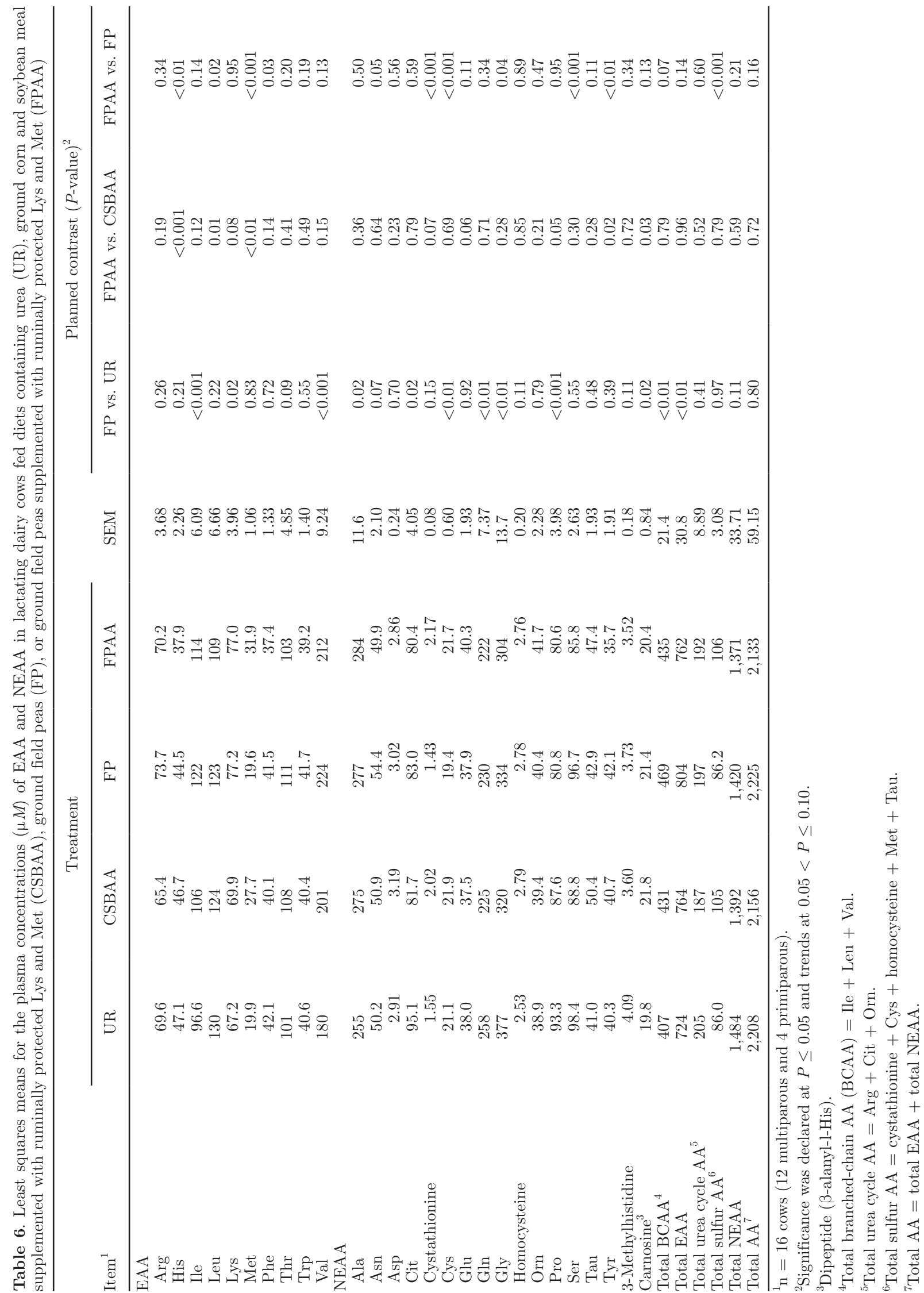


Table 7. Means for variables predicted by the NRC (2001) model in lactating dairy cows fed diets containing urea (UR), ground corn and soybean meal supplemented with ruminally protected Lys and Met (CSBAA), ground field peas (FP), or ground field peas supplemented with ruminally protected Lys and Met (FPAA)

\begin{tabular}{lcccc}
\hline & \multicolumn{4}{c}{ Treatment } \\
\cline { 2 - 5 } Item $^{1}$ & $\mathrm{UR}$ & $\mathrm{CSBAA}$ & $\mathrm{FP}$ & FPAA \\
\hline $\mathrm{NE}_{\mathrm{L}}$-allowable milk, kg/d & 38.5 & 42.9 & 41.5 & 41.4 \\
$\mathrm{NE}_{\mathrm{L}}$ balance, Mcal/d & -2.30 & 0.00 & -0.80 & -0.90 \\
MP-allowable milk, kg/d & 32.5 & 39.2 & 33.5 & 33.4 \\
RDP, \% of DMI & 11.1 & 9.30 & 10.7 & 10.7 \\
RUP, \% of DMI & 4.20 & 5.70 & 4.20 & 4.30 \\
RDP balance, g/d & 254 & -146 & 200 & 212 \\
RUP balance, g/d & -483 & -192 & -480 & -496 \\
MP bacterial, g/d & 1,268 & 1,268 & 1,328 & 1,346 \\
MP RUP, g/d & 809 & 1,218 & 850 & 879 \\
MP endogenous, g/d & 110 & 118 & 116 & 118 \\
MP total, g/d & 2,187 & 2,604 & 2,294 & 2,346 \\
MP balance, g/d & -396 & -163 & -393 & -407 \\
Digestible Lys flow, \% of MP & 6.75 & 6.58 & 7.05 & 7.30 \\
Digestible Met flow, \% of MP & 1.96 & 2.20 & 1.84 & 2.33 \\
Digestible His flow, \% of MP & 2.12 & 2.08 & 2.08 & 2.05 \\
Digestible EAA flow, \% of MP & 44.9 & 43.7 & 44.8 & 45.2 \\
Digestible Lys flow, g/d & 148 & 171 & 162 & 171 \\
Digestible Met flow, g/d & 42.9 & 57.3 & 42.2 & 54.5 \\
Digestible His flow, g/d & 46.4 & 54.2 & 47.7 & 48.1 \\
Digestible EAA flow, g/d & 982 & 1,137 & 1,026 & 1,056 \\
Lys:Met ratio in MP & $3.44: 1$ & $2.99: 1$ & $3.82: 1$ & $3.13: 1$ \\
\hline
\end{tabular}

${ }^{1}$ Actual feed nutritional composition and animal variables (i.e., DMI, milk yield and composition, DIM, and BW) were used in the NRC (2001) evaluation software.

this diet (Table 2). All 4 diets resulted in negative MP balances due to the low concentration of dietary $\mathrm{CP}$ $($ mean $=15.1 \%$, Table 2$)$ and predicted RUP $($ mean $=$ $4.6 \%$ of DMI; Table 7 ).

\section{CONCLUSIONS}

Our hypothesis that feeding FP compared with UR would increase milk yield and $\mathrm{N}$ utilization due to increased DMI, nutrient digestibility, and microbial protein synthesis was proven correct. Milk yield and milk protein synthesis were similar in cows fed CSBAA versus FPAA, thereby confirming our second hypothesis. Our third hypothesis that milk protein synthesis would increase by supplementing GFP with RP-Lys and RPMet was not confirmed as concentration, but not yield of milk true protein increased in cows fed FPAA vs FP. Further research is needed to better understand the metabolic factors involved in the reduction of His, Leu, and Phe concentrations in plasma when feeding $25 \%$ of GFP (DM basis) supplemented with RP-Lys and RPMet supplements to high-producing dairy cows.

\section{ACKNOWLEDGMENTS}

This work was financially supported by the USDA National Institute of Food and Agriculture (Hatch Multistate NC-1042 Project Number NH00616-R; Project
Accession Number 1001855), the New Hampshire Agricultural Experiment Station (Durham, NH), and Adisseo (Antony, France). This is the New Hampshire Agricultural Experiment Station Scientific Contribution Number 2731. Gratitude is extended to Ajinomoto Heartland Inc. (Tokyo, Japan) for donating AjiproL. We also thank the University of New Hampshire (Durham, NH) graduate students Kelsey Juntwait and Brianna Isenberg, and undergraduate student (Kelly O'Connor) for animal care and sample collections. Monica Stimmel (Virginia Polytechnic Institute and State University, Blacksburg, VA) is acknowledged for her support during feeding and sampling. We also thank the University of New Hampshire Fairchild Teaching and Research Dairy Center manager Jon Whitehouse and his staff for excellent animal care and overall research support.

\section{REFERENCES}

Aharoni, Y., H. Tagari, and R. C. Boston. 1991. A new approach to the quantitative estimation on nitrogen metabolic pathways in the rumen. Br. J. Nutr. 66:407-422.

Albrecht, J. J. 2012. Replacing corn and soybean meal in lactating dairy cow diets with field peas (Psium sativum). MS thesis. Dairy and Food Science Department, South Dakota State University, Brookings.

Allison, M. J. 1970. Nitrogen metabolism of ruminal micro-organisms. Page 456-472 in Physiology of Digestion and Metabolism in the Ruminant. A. T. Phillipson, ed. Oriel Press, Newcastle, UK. 
Argyle, J. L., and R. L. Baldwin. 1989. Effects of amino acids and peptides on rumen microbial growth yields. J. Dairy Sci. 72:20172027. https://doi.org/10.3168/jds.S0022-0302(89)79325-5.

AOAC. 1990. Official Methods of Analysis. 15th ed. Assoc. Off. Anal. Chem., Arlington, VA.

AOAC International. 1998. Official Methods of Analysis. 16th ed. AOAC International, Arlington, VA.

AOAC International. 2006. Official Methods of Analyses, 18th ed. AOAC International, Gaithersburg, MD.

AOAC International. 2016. Official Methods of Analyses, 20th ed. AOAC International, Gaithersburg, MD.

Atasoglu, C., C. Valdes, C. J. Newbold, and R. J. Wallace. 1999. Influence of peptides and amino acids on fermentation rate and de novo synthesis of amino acids by mixed microorganisms from the sheep rumen. Br. J. Nutr. 81:307-314.

Berthiaume, R., P. Dubreuil, M. Stevenson, B. W. McBride, and H. Lapierre. 2001. Intestinal disappearance and mesenteric and portal appearance of amino acids in dairy cow fed ruminally protected methionine. J. Dairy Sci. 84:194-203.

Brito, A. F., and G. A. Broderick. 2007. Effects of different protein supplements on milk production and nutrient utilization in lactating dairy cows. J. Dairy Sci. 90:1816-1827. https://doi. org $/ 10.3168 /$ jds.2006-558.

Brito, A. F., G. A. Broderick, and S. M. Reynal. 2007. Effects of different protein supplements on omasal nutrient flow and microbial protein synthesis in lactating dairy cows. J. Dairy Sci. 90:1828 1841. https://doi.org/10.3168/jds.2006-559.

Broderick, G. A., and W. J. Radloff. 2004. Effect of molasses supplementation on the production of lactating dairy cows fed diets based on alfalfa and corn silage. J. Dairy Sci. 87:2997-3009. https://doi.org/10.3168/jds.S0022-0302(04)73431-1.

Bryant, M. P. 1973. Nutritional requirements of the predominant rumen cellulolytic bacteria. Fed. Proc. 32:1809-1813.

Carro, M. D., and E. L. Miller. 1999. Effect of supplementing a fibre basal diet with different nitrogen forms on ruminal fermentation and microbial growth in an in vitro semi-continuous culture system (RUSITEC). Br. J. Nutr. 82:149-157. https://doi.org/10.1017/ S0007114599001300.

Chen, X. B., Y. K. Chen, M. F. Franklin, E. R. Ørskov, and W. J. Shand. 1992. The effect of feed intake and body weight on purine derivative excretion and microbial protein supply in sheep. J. Anim. Sci. 70:1534-1542.

Chikunya, S., C. J. Newbold, L. Rode, X. B. Chen, and R. J. Wallace, 1996. Influence of dietary rumen-degradable protein on bacterial growth in the rumen of sheep receiving different energy sources. Anim. Feed Sci. Technol. 63:333-340.

Cochran, R. C., D. C. Adams, J. D. Wallace, and M. L. Galyean. 1986. Predicting digestibility of different diets with internal markers: Evaluation of four potential markers. J. Anim. Sci. 63:1476-1487. https://doi.org/10.2134/jas1986.6351476x.

Cotta, M. A., and J. B. Russell. 1982. Effect of peptides and amino acids on efficiency of rumen bacterial protein synthesis in continuous culture. J. Dairy Sci. 67:226-234. https://doi.org/10.3168/jds. S0022-0302(82)82181-4.

Deyl, Z., J. Hyanek, and M. Horakova. 1986. Profiling of amino acids in body fluids and tissues by means of liquid chromatography. J. Chromatogr. 379:177-250. https://doi.org/10.1016/S03784347(00)80685-4.

Erdman, R. A., R. D. Shaver, and J. H. Vandersall. 1984. Dietary choline for the lactating cow: Possible effects on milk fat synthesis. J. Dairy Sci. 67:410-415. https://doi.org/10.3168/jds.S00220302(84)81317-X.

Fekkes, D. 1996. State-of-the-art of high-performance liquid chromatographic analysis of amino acids in physiological samples. J. Chromatogr. B Biomed. Appl. 682:3-22. https://doi.org/10.1016/03784347(96)00057-6.

Fredin, S. M., L. F. Ferraretto, M. S. Akins, S. J. Bertics, and R. D. Shaver. 2015. Effects of corn-based diet starch content and corn particle size on lactation performance, digestibility, and bacterial protein flow in dairy cows. J. Dairy Sci. 98:541-553. https://doi. org/10.3168/jds.2014-8502.
Froidmont, E., and N. Bartiaux-Thill. 2004. Suitability of lupin and pea seeds as a substitute for soybean meal in high-producing dairy cow feed. Anim. Res. 53:475-487. https://doi.org/10.1051/ animres:2004034.

Gaines, W. L., and F. A. Davidson. 1923. Relation between percentage fat content and yield of milk. Bull. 245. Ill. Agric. Expt. Sta., Urbana, IL.

Giallongo, F., M. T. Harper, J. Oh, J. C. Lopes, H. Lapierre, R. A. Patton, C. Parys, I. Shinzato, and A. N. Hristov. 2016. Effects of rumen-protected methionine, lysine, and histidine on lactation performance of dairy cows. J. Dairy Sci. 99:4437-4452. https:/ doi.org/10.3168/jds.2015-10822.

Gilbery, T. C., G. P. Lardy, S. A. Soto-Navarro, M. L. Bauer, and V. L. Anderson. 2007. Effect of field peas, chickpeas, and lentils on rumen fermentation, digestion, microbial protein synthesis, and feedlot performance in receiving diets for beef cattle. J. Anim. Sci. 85:3045-3053. https://doi.org/10.2527/jas.2006-651.

Griswold, K. E., W. H. Hoover, T. K. Miller, and W. V. Thayne. 1996 Effect of form of nitrogen on growth of ruminal microbes in continuous culture. J. Anim. Sci. 74:483-491.

Hall, M. B., W. H. Hoover, J. P. Jennings, and T. K. M. Webster. 1999. A method for partitioning neutral detergent soluble carbohydrates. J. Sci. Food Agric. 79:2079-2086.

Huhtanen, P., K. Kaustell, and S. Jaakkola. 1994. The use of internal markers to predict total digestibility and duodenal flow of nutrients in cattle given six different diets. Anim. Feed Sci. Technol. 48:211-227. https://doi.org/10.1016/0377-8401(94)90173-2.

Kertz, A. F. 2010. Review: Urea feeding to dairy cattle: A historical perspective and review. Prof. Anim. Sci. 26:257-272. https://doi. org/10.15232/S1080-7446(15)30593-3.

Khorasani, G. R., E. K. Okine, R. R. Corbett, and J. J. Kennelly 2001. Nutritive value of peas for lactating dairy cattle. Can. J. Anim. Sci. 81:541-551. https://doi.org/10.4141/A01-019.

Knowlton, K. F., B. P. Glenn, and R. A. Erdman. 1998. Performance, ruminal fermentation, and site of starch digestion in early lactation cows fed corn grain harvested and processed differently. J. Dairy Sci. 81:1972-1984. https://doi.org/10.3168/jds.S00220302(98)75771-6.

Lee, C., A. N. Hristov, T. W. Cassidy, K. S. Heyler, H. Lapierre, G. A. Varga, M. J. de Veth, R. A. Patton, and C. Parys. 2012. Rumenprotected lysine, methionine, and histidine increase milk protein yield in dairy cows fed a metabolizable protein-deficient diet. J. Dairy Sci. 95:6042-6056. https://doi.org/10.3168/jds.2012-5581.

Licitra, G., T. M. Hernandez, and P. J. Van Soest. 1996. Standardization of procedures for nitrogen fractionation of ruminant feeds. Anim. Feed Sci. Technol. 57:347-358. https://doi. org/10.1016/0377-8401(95)00837-3.

Masoero, F., M. Moshcini, G. Fusconi, and G. Piva. 2006. Raw, extruded and expanded pea (Pisum sativum) in dairy cows diets. Ital J. Anim. Sci. 5:237-247. https://doi.org/10.4081/ijas.2006.237.

Nolan, J. 1975. Quantitative models of nitrogen metabolism in sheep. Pages 416-431 in Digestion and Metabolism in the Ruminant. I. W. McDonald and A. C. I. Warner, ed. University of New England Publishing Unit, Armidale, New South Wales, Australia.

NRC. 2001. Nutrient Requirements of Dairy Cattle. 7th rev. ed. Natl. Acad. Sci., Washington, DC.

Offner, A., A. Bach, and D. Sauvant. 2003. Quantitative review of in situ starch degradation in the rumen. Anim. Feed Sci. Technol. 106:81-93. https://doi.org/10.1016/S0377-8401(03)00038-5.

Patton, R. A., A. N. Hristov, C. Parys, and H. Lapierre. 2015. Relationships between circulating plasma concentrations and duodenal flows of essential amino acids in lactating dairy cows. J. Dairy Sci. 98:4707-4734. https://doi.org/10.3168/jds.2014-9000.

Petit, H. V., R. Rioux, and D. R. Ouellet. 1997. Milk production and intake of lactating cows fed raw or extruded peas. J. Dairy Sci. 80:3377-3385. https://doi.org/10.3168/jds.S0022-0302(97)763136.

Piepenbrink, M. S., and T. R. Overton. 2003. Liver metabolism and production of cows fed increasing amounts of rumen-protected choline during the periparturient period. J. Dairy Sci. 86:17221733. https://doi.org/10.3168/jds.S0022-0302(03)73758-8. 
Reynal, S. M., I. R. Ipharraguerre, M. Liñeiro, A. F. Brito, G. A. Broderick, and J. H. Clark. 2007. Omasal flow of soluble proteins, peptides, and free amino acids in dairy cows fed diets supplemented with proteins of varying ruminal degradabilities. J. Dairy Sci. 90:1887-1903. https://doi.org/10.3168/jds.2006-158.

Reynolds, C. K., and N. B. Kristensen. 2008. Nitrogen recycling through the gut and the nitrogen economy of ruminants: An asynchronous symbiosis. J. Anim. Sci. 86(Suppl.):E293-E305. https:// doi.org/10.2527/jas.2007-0475.

Rosenthal, H. L. 1955. Determination of urea in blood and urine with diacetyl monoxime. Anal. Chem. 27:1980-1982. https://doi. org/10.1021/ac60108a039.

Tyrrell, H. F., and J. T. Reid. 1965. Prediction of the energy value of cow's milk. J. Dairy Sci. 48:1215-1223. https://doi.org/10.3168/ jds.S0022-0302(65)88430-2.

Valadares, R. F. D., G. A. Broderick, S. C. V. Filho, and M. K. Clayton. 1999. Effect of replacing alfalfa silage with high mois- ture corn on ruminal protein synthesis estimated from excretion of total purine derivatives. J. Dairy Sci. 82:2686-2696. https://doi. org/10.3168/jds.S0022-0302(99)75525-6.

Van Soest, P. J., J. B. Robertson, and B. A. Lewis. 1991. Methods for dietary fiber, neutral detergent fiber, and nonstarch polysaccharides in relation to animal nutrition. J. Dairy Sci. 74:3583-3597. https://doi.org/10.3168/jds.S0022-0302(91)78551-2.

Vander Pol, M., A. N. Hristov, S. Zaman, and N. Delano. 2008. Peas can replace soybean meal and corn grain in dairy cow diets. J. Dairy Sci. 91:698-703. https://doi.org/10.3168/jds.2007-0543.

Vander Pol, M., A. N. Hristov, S. Zaman, N. Delano, and C. Schneider. 2009. Effect of inclusion of peas in dairy cow diets on ruminal fermentation, digestibility, and nitrogen losses. Anim. Feed Sci. Technol. 150:95-105. https://doi.org/10.1016/j.anifeedsci.2008.08.009.

Wu, G. 2013. Amino acids: Biochemistry and Nutrition. CRC Press, Boca Raton, FL. 